\title{
SUITABILITY OF ELECTRICAL CONDUCTIVITY TESTING AND ACCELERATED AGING FOR EVALUATING THE VIGOR OFCITHAREXYLUM MYRIANTHUM CHAM. DIASPORES
}

\author{
Ana Paula Bazzanella ${ }^{1 *}$, Gabriele Larissa Mathias ${ }^{2}$, Henrique Roberto Gattermann Mittelstaedt ${ }^{3}$, Maiara \\ Iadwizak Ribeiro ${ }^{4}$, Andréa Maria Teixeira Fortes ${ }^{5}$, Jaqueline Malagutti Corsato ${ }^{6}$. \\ 1*Universidade Estadual do Oeste do Paraná, Centro de Ciências Biológicas e da Saúde, Cascavel, Paraná, Brasil -apbazz@hotmail.com *; \\ gabriele.mathias@hotmail.com; henrique.roberto97@gmail.com; maiara_maa@hotmail.com; amtfortes@hotmail.com; \\ jaque_corsato@hotmail.com \\ Recebido para publicação: 06/02/2018 - Aceito para publicação: 15/03/2019
}

\begin{abstract}
Resumo
Adequação do teste de condutividade elétrica e envelhecimento acelerado para a avaliação do vigor de diásporos de Citharexylum myrianthum CHAM. A Mata Atlântica é um dos biomas brasileiros mais ameaçados pela ação antrópica. Com isso, vem crescendo o interesse pela recuperação das áreas degradadas através do uso de espécies arbóreas nativas, acarretando uma alta demanda no uso de sementes vigorosas. Esta pesquisa objetivou a adequação do teste de condutividade elétrica e envelhecimento acelerado para avaliação do vigor de diásporos de Citharexylum myrianthum. Para a adequação do teste de condutividade elétrica foi utilizado delineamento experimental inteiramente casualizado (DIC), em esquema fatorial $2 \times 3 \times 9$ (número de diásporos $\mathrm{x}$ volume de água $\mathrm{x}$ tempo de embebição) à temperatura constante de $25^{\circ} \mathrm{C} . \mathrm{O}$ procedimento para o teste de envelhecimento acelerado foi conduzido à $40{ }^{\circ} \mathrm{C}$ durante 0 (sem envelhecimento), 24, 48 e 72 horas. Para $\mathrm{o}$ teste de envelhecimento acelerado foi utilizado o DIC, totalizando 4 tratamentos. Os resultados foram submetidos a análise de variância (ANOVA) e as médias comparadas pelo teste de Tukey a 5\% de probabilidade. Conclui-se que o teste de condutividade elétrica para os diásporos de C. myrianthum, pode ser conduzido com 25 diásporos embebidos com $50 \mathrm{~mL}$ de água deionizada por 96 horas, substituindo assim o teste de germinação com a vantagem de ser realizado em um menor período de tempo. E o período de 24 e 48 horas de envelhecimento acelerado é adequado para discriminar o vigor dos diásporos de C. myrianthum, sendo o IVG e o TMG as variáveis mais sensíveis.

Palavras-Chave: Recuperação de áreas degradadas; sementes nativas, produção de mudas, sementes viáveis.
\end{abstract}

\begin{abstract}
The Atlantic Forest is one of the most threatened Brazilian biomes by anthropic action. Thus, the interest inrecovering degraded areas through the use of native tree species has increased, causing a high demand in the use of vigorous seeds. This research aimed at evaluating the suitabilityof the electrical conductivity and accelerated aging tests to evaluate the vigor of $C$. myrianthum diaspores. For the adequacy of the electrical conductivity test, a completely randomized experimental design (CRD) was used in a $2 \times 3 \times 9$ (number of diaspores $\mathrm{x}$ volume of water $\mathrm{x}$ imbibition time)at a constant temperature of $25{ }^{\circ} \mathrm{C}$. The procedure for the accelerated aging test was conducted at $40^{\circ} \mathrm{C}$ for 0 (no aging), 24, 48 and 72 hours. ACRDwas also used for the accelerated aging test, totaling 4 treatments. The results were submitted to analysis of variance (ANOVA) and the means were compared by the Tukey test at $5 \%$ probability. It is concluded that the electrical conductivity test for $C$. myrianthum diaspores can be conducted with 25 diaspores soaked with $50 \mathrm{~mL}$ of deionized water for 96 hours, thus replacing the germination test with the advantage of being carried out in a shorter period of time. Moreover,the 24 and 48 hour accelerated aging period is adequate to discriminate the vigor of $C$. myrianthum diaspores, with GSI and MGT being the most sensitive variables. Keywords: Recovery of degraded areas; native seeds, seedling production, viable seeds.
\end{abstract}

\section{INTRODUCTION}

The Atlantic Forest is one of the most threatened Brazilian biomes by anthropic action, currently leaving only $12.4 \%$ of the original vegetation cover (SOS Atlantic Forest, 2018), of which only $15.2 \%$ of its original area is preserved in fragments of more than 3 ha (FUNDAÇÃO SOS MATA ATLÂNTICA; INPE, 2018). However, even though small and fragmented, it is estimated that this biome is home to about $35 \%$ of Brazil's plant species, many of which are endemic and endangered (MMA, 2018). 
In this context, we can observe several funding and resource availability initiatives for ecological restoration and restoration of degraded and disturbed areas. Thus, there is a growing use of native tree species in environmental recovery and natural resource conservation programs, resulting in a high demand for seed production (ALMEIDA, 2016).

For AOSA (1983) "seed vigor comprises intrinsic properties of the seed itself which determine the potential for rapid and uniform emergence and normal seedling development under a wide range of environmental conditions." For Marcos Filho (2015), the vigor test seeks to identify significant differences in the physiological potential of similar germinating lots, thus aiming to use vigorous seeds in the field, and thereby ensuring recovery.

With this, success in seedling production depends on knowledge of the formation processes and germination power of each species and the quality of the seed used, as well as the storage conditions and germination behavior of native seeds (DAVIDE et al., 2003; MACHADO et al., 2016). Thus, the importance of evaluating the physiological potential of seed lots through vigor tests is clear, enabling identification of larger and smaller vigor lots with results generated in a short time period. This enables technologists, producers and researchers to obtain a suitable seedling stand under different field conditions (MEDEIROS et al.,2017).

Germination of native species is generally slow and uneven, which is a fact generally associated with seed dormancy, resulting in a delay to obtain information on the quality of the seed lots to be used. Thus, we can mention the electrical conductivity (EC) and accelerated aging (AA) tests as the main rapid vigor tests (MARCOS FILHO, 2015). The EC is a biochemical test which evaluates the biochemical changes in the plasma membrane associated with vigor; in it, the higher the leachate rates released in the seed soaking water, the greater the damage to the membrane, and the lower the seed lot vigor (DALANHOL et al., 2014). Factors which may affect the EC test results are: species evaluated, immersion time, water content, weight, volume and number of seeds, seed immersion water content, seed integrity and age, genotype and temperature (MEDEIROS et al., 2017).

On the other hand, the AA test evaluates seed performance exposed to adverse conditions such as high temperatures and moisture which induce oxidative reactions in seed cell constituents, thus simulating what occurs in natural seed aging, but faster (MORAES et al., 2016). Knowing the characteristics of physiological and biochemical changes under AA conditions are useful to better understand the seed deterioration process. Such factors result in reduced germination speed and percentage, as well as increased formation of abnormal seedlings (ARAÚJO et al., 2017).

Research on the standardization of vigor tests for forest species is directed to studies on the influence of different factors on the final results, such as number of seeds, volume, soaking period and temperature (MEDEIROS et al., 2017).

One species indicated and used for reclamation of degraded areas is Citharexylum myrianthum Cham, which belongs to the Verbenaceae family, popularly known as tucaneiro and tarumã. It is pollinated by moths, butterflies, hummingbirds, bees and small insects. The fruits are reddish in color, ripen in January-March and are very appetizing for various species of generalist birds (AMARAL et al., 2013). This species is commonly found in the Atlantic rainforest, gallery or riparian forest, Semi-deciduous Seasonal Forest and Mixed Ombrophilous Forest. C. myrianthum is classified as an early secondary pioneer, fast growing and adapted to very humid and swampy; it is indispensable in mixed plantations intended for recomposing degraded riparian areas(LORENZI, 2014).

In this context, Moraes et al.(2016) point out that studies aiming at the adequacy of vigor tests for native species are promising, as they present agility in obtaining results and efficient discrimination of vigorous seed lots; however, the authors point out that the gap in the number of studies focused on the adequacy of these tests is still remarkable. Therefore, the objective of this study was to adapt the adequacy of the EC and AA tests in evaluating the diaspore quality of C. myrianthum.

\section{MATERIALSAND METHODS}

The experiment was carried out at the Plant Physiology Laboratory of the Western Paraná State University - UNIOESTE, Cascavel - PR campus, from April to November 2017. The C. myrianthum diaspores used in the study were collected in February 2017 and donated by the Forest Nursery of the Bela Vista da ITAIPU Biological Refuge. Four replications of 25 diaspores were used to obtain the moisture degree, which were placed in aluminum containers with known mass and then oven dried at $105 \pm 3{ }^{\circ} \mathrm{C}$ for 24 hours. The moisture content of the diaspores 
was determined by the difference in mass obtained after 24 hours in the greenhouse, according to the rules for seed analysis (RAS) (BRASIL, 2009).

The mass of one thousand seeds was determined according to the recommendations of Brasil( $R A S)$ (2009), using eight replications of 100 diaspores from the pure seed portion of each batch, where each sample was individually weighed and the result expressed in grams.

For the germination test characterization, C. myrianthum diaspores were placed on Germitest paper moistened with distilled water at a ratio of 2.5 times the dry mass of the paper. Eight repetitions of 50 diaspores were used. After the experiment was installed, the paper rolls were placed in plastic bags and then in a germination chamber (B.O.D) with a constant temperature of $25^{\circ} \mathrm{C}$ and 12 hours light/dark photoperiod.

The number of germinated diaspores was counted every 48 hours until the $36^{\text {th }}$ day after installing the test, following the criteria established in the instructions for seed analysis of forest species (BRASIL, 2013), with the diaspores having a primary root length equal to or greater than $2 \mathrm{~mm}$ being considered germinated (LABOURIAU, 1983). The following parameters were analyzed at the end of the C. myrianthum diaspore germination characterization test: Germination percentage (GP), mean germination time (MGT) (NAGAKAWA, 1994), germination speed index (GSI) and germination frequency and synchronization (RANAL; SANTANA, 2006).

For the adequacy of the EC test, a $2 \times 3 \times 9$ factorial scheme (number of diaspores $\mathrm{x}$ amount of water $\mathrm{x}$ soaking time) was performed using 25 and 50 diaspores which were packaged in plastic cups containing 50, 75 and $100 \mathrm{~mL}$ of deionized water, thus totaling six treatments. Each treatment with 8 repetitions was maintained in a germination chamber (B.O.D.) with a constant temperature of $25^{\circ} \mathrm{C}$ and a 12-hour photo-period. The EC was evaluated after 2, 4, 8, 12, 24, 30, 36, 48 and 96 hours of soaking.In order to quantify the leached electrolytes, the samples were mixed to homogenize the exudates released in the water, and the EC was read from the diaspore soaking solution using a pre-calibrated model $\mathrm{mCA} 150$ bench conductivity meter with constant 1.0 electrode. The results were expressed as $\mu \mathrm{S} \mathrm{cm}^{-1} \mathrm{~g}^{-1}$.

The AA test was performed on the C. myrianthum diaspores after the EC test adequacy procedure. This test was conducted by conditioning the diaspores under a wire mesh attached to gerbox-type plastic boxes, forming humid mini chambers. Next, $50 \mathrm{~mL}$ of distilled water was added inside the boxes, then capped and kept inside germination chambers (B.O.D.) under constant temperature conditions of $40^{\circ} \mathrm{C}$, and relative humidity near $100 \%$ for a time period of $0,24,48,72$ hours.

C. myrianthum diaspores were subsequently submitted to the germination test and ECat each AA period. The germination test was conducted on moist Germitest paper at a ratio of 2.5 times the dry weight of the paper using eight repetitions of 50 paper diaspores, and were then placed in a germination chamber (B.O.D.) at a constant temperature of $25^{\circ} \mathrm{C}$ and a photoperiod of 12 hours. The number of germinated diaspores was counted every 48 hours until the $36^{\text {th }}$ day after installing the test, following the criteria established in the Instructions for seed analysis of forest species (BRASIL, 2013), with the diaspores that present primary root length equal to or greater than 2 mm being considered as germinated (LABOURIAU, 1983).

The EC test was performed using 25 diaspores soaked in $50 \mathrm{~mL}$ of deionized water for each AA period, and readings were taken 96 hours after installing the test. In order to quantify the leached electrolytes, the samples were mixed to homogenize the exudates released in the water, and the EC was read from the diaspore soaking solution using a pre-calibrated model mCA 150 bench conductivity meter with constant 1.0 electrode. The results were expressed in $\mu \mathrm{S} \mathrm{cm}^{-1} \mathrm{~g}^{-1}$.

A completely randomized experimental design (CRD) was used in a $2 \times 3 \times 9$ factorial scheme for the electrical conductivity test. An analysis of variance (ANOVA) was performed and a comparison of the means of all evaluated treatments were done by the Tukey test at 5\% probability by the SISVAR program.

A completely randomized experimental design (CRD) totaling 4 treatments was used for the accelerated aging test. The analysis of variance (ANOVA) was performed and a comparison of the means of all evaluated treatments was performed by the Tukey test at $5 \%$ probability in the Assistat statistical program.

\section{RESULTS}

FLORESTA, Curitiba, PR, v. 49, n. 4, p. 701 - 708, out/dez 2019. 
The $C$. myrianthum diaspores used in the study presented a water content of $8.8 \%$ and a mass of one thousand seeds of $66.6 \mathrm{~g}$. The germination test presented a germination percentage of $44 \%$, taking an average of 15 days for the process to be completed with a germination speed of 12.01 and a synchronization index of 2.60 (Figure 1). It can be observed that this species has a high frequency and a high synchronization index of the process, meaning that the species presented spaced out germination over time, starting at 8 days and reaching a germination peak on the $10^{\text {th }}$ to $12^{\text {th }}$ day (Figure 1 ).

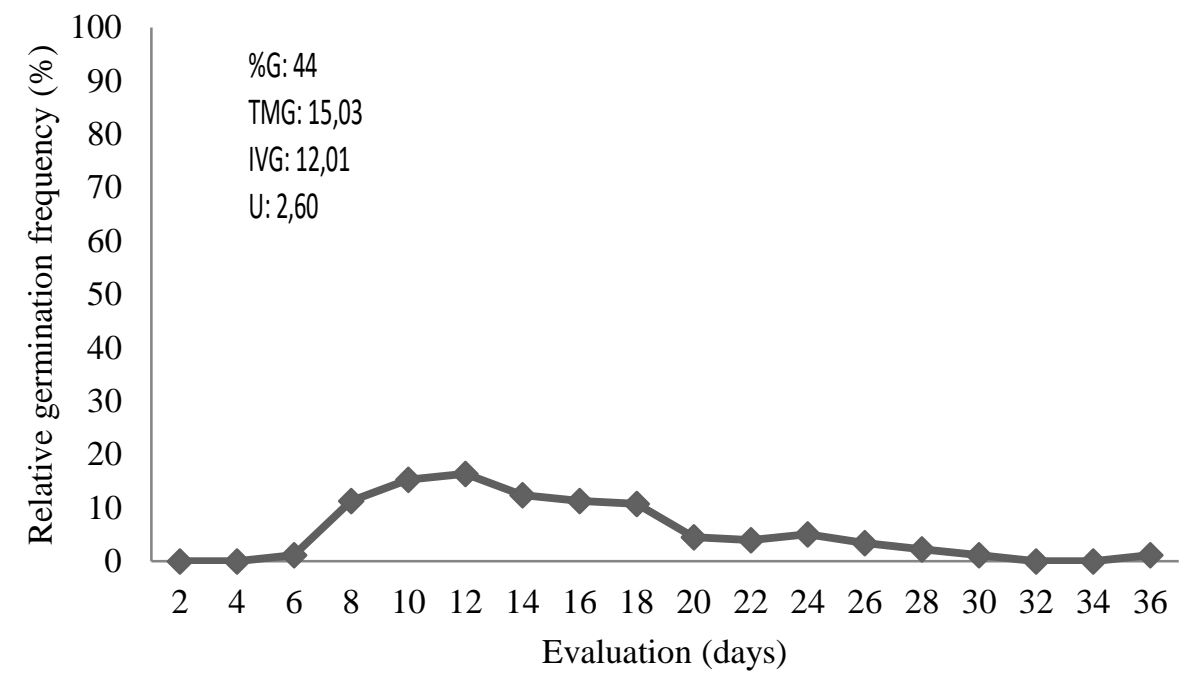

Figura 1. Frequência relativa da germinação $(\%)$, porcentagem $(\% \mathrm{G})$, tempo médio [TMG (dias)], índice de velocidade (IVG) e sincronização (U) da germinação de diásporos de C. myrianthum.

Figure 1. Relative germination frequency $(\%)$, percentage $(\mathrm{G} \%)$, mean germination time [MGT (days)], germination speed index (GSI) and synchronization (U) of C. myrianthum diaspores.

For the EC test, the $2 \times 3 \times 9$ factorial analysis (number of seeds $\mathrm{x}$ amount of water $\mathrm{x}$ soaking time) was significant ( $\mathrm{p}<0.05)$, but their double splits are presented in this work to facilitate interpreting the data. It is noteworthy that the EC values of $C$. myrianthum diaspores in the unfolding of the factors that the number of diaspores $x$ soaking time was not significant ( $p>0.05$ ), presenting on average $27.63 \mu \mathrm{S} \mathrm{cm}^{-1} \mathrm{~g}^{-1}$.

The analysis of the interaction between the factors number of diaspores $\mathrm{x}$ water volume used in the EC test was significant ( $\mathrm{p}<0.05$ ) (Table 1). Using 25 C. myrianthum diaspores showed the highest EC values for both the $50 \mathrm{~mL}$ and $100 \mathrm{~mL}$ volumes of deionized water $\left(35.38 \mu \mathrm{S} \mathrm{cm}^{-1} \mathrm{~g}^{-1}\right.$ and $19.79 \mu \mathrm{S} \mathrm{cm}^{-1} \mathrm{~g}^{-1}$, respectively). However, it was observed that the highest EC value when using $75 \mathrm{~mL}$ of deionized water was with using 50 diaspores $\left(32.82 \mu \mathrm{S} \mathrm{cm}^{-1} \mathrm{~g}^{-1}\right)$ (Table 1).

When using 25 diaspores of the species under study, the highest EC values were observed with the use of $50 \mathrm{~mL}$ of deionized water, whereas the use of 50 and $75 \mathrm{~mL}$ did not differ statistically for 50 diaspores $(\mathrm{p}>0.05)$, while the use of $100 \mathrm{~mL}$ of water reduced the EC values by almost half $\left(18.13 \mu \mathrm{S} \mathrm{cm}^{-1} \mathrm{~g}^{-1}\right)$ (Table 1).

Tabela 1. Condutividade elétrica $\left(\mu \mathrm{S} \mathrm{cm}^{-1} \mathrm{~g}^{-1}\right)$ de diásporos de C. myrianthum. Em função do número de diásporos (25 e 50) e do volume de água deionizada para embebição $(50,75$ e $100 \mathrm{~mL})$

Table 1. Electrical conductivity $\left(\mu \mathrm{S} \mathrm{cm}^{-1} \mathrm{~g}^{-1}\right)$ of $C$. myrianthum diaspores as a function of the number of diaspores (25 and 50) and the volume of deionized water for soaking $(50,75$ and $100 \mathrm{~mL})$.

\begin{tabular}{rccc}
\hline No. Of diaspores & $50 \mathrm{~mL}$ & $75 \mathrm{~mL}$ & $100 \mathrm{~mL}$ \\
\hline 25 & $35.38 \mathrm{aA}$ & $26.11 \mathrm{bB}$ & $19.79 \mathrm{aC}$ \\
50 & $33.92 \mathrm{bA}$ & $32.82 \mathrm{aA}$ & $18.13 \mathrm{bB}$ \\
\hline
\end{tabular}

Averages followed by the same lowercase letter in the column and uppercase in the row do not differ by Tukey test at $5 \%$ probability.

The interaction of the factors water volume $x$ soaking time (hours) was significant ( $p<0.05)$ (Table 2). Regardless of the amount of water used, the highest EC values for $C$. myrianthum diaspores were obtained after 96 hours of soaking. It was also observed that the use of $50 \mathrm{~mL}$ of deionized water resulted in on average two 
times higher EC values than those samples that were conditioned in $100 \mathrm{~mL}$ of deionized water in all evaluated periods (Table 2).

Tabela 2. Condutividade elétrica $\left(\mu \mathrm{S} \mathrm{m}^{-1} \mathrm{~g}^{-1}\right)$ de diásporos de $C$. myrianthum em função do volume de água deionizada para embebição $(50,75$ e $100 \mathrm{~mL})$ e tempo de embebição $(2,4,8,12,24,30,36,48$ e 96 horas).

Table 2. Electrical conductivity $\left(\mu \mathrm{S} \mathrm{cm} \mathrm{cm}^{-1} \mathrm{~g}^{-1}\right.$ ) of $C$. myrianthum diaspores in function of the volume of deionized water for immersion $(50,75$ and $100 \mathrm{~mL})$ and soaking time $(2,4,8,12,24,30,36,48$ and 96 hours).

\begin{tabular}{cccccccccccccccc}
\hline $\mathrm{mL}$ & $2 \mathrm{H}$ & $4 \mathrm{H}$ & $8 \mathrm{H}$ & $12 \mathrm{H}$ & $24 \mathrm{H}$ & $30 \mathrm{H}$ & $36 \mathrm{H}$ & $48 \mathrm{H}$ \\
$\mathrm{H}_{2} \mathrm{O}$ & & & & & & & & & \\
\hline 50 & $20.85 \mathrm{aF}$ & $24.83 \mathrm{aE}$ & $28.90 \mathrm{aB}$ & $28.79 \mathrm{aD}$ & $31.30 \mathrm{aD}$ & $34.64 \mathrm{aC}$ & $35.70 \mathrm{aC}$ & $42.88 \mathrm{aB}$ & $63.95 \mathrm{aA}$ \\
75 & $16.89 \mathrm{bF}$ & $20.88 \mathrm{bE}$ & $24.18 \mathrm{bD}$ & $23.44 \mathrm{bDE}$ & $28.86 \mathrm{Bc}$ & $30.50 \mathrm{Bc}$ & $31.43 \mathrm{bC}$ & $35.85 \mathrm{bB}$ & $53.15 \mathrm{bA}$ \\
100 & $10.70 \mathrm{Cf}$ & $13.52 \mathrm{cEF}$ & $16.15 \mathrm{cDE}$ & $16.35 \mathrm{cDE}$ & $18.27 \mathrm{cCD}$ & $19.06 \mathrm{cCD}$ & $20.06 \mathrm{cBC}$ & $23.16 \mathrm{cB}$ & $33.37 \mathrm{cA}$ \\
\hline
\end{tabular}

Averages followed by the same lowercase letter in the column and uppercase in the row do not differ from each other by the Tukey test at $5 \%$ probability.

The AA analysis (Table 3) shows that the ECofC. myrianthum diaspores decreased significantly $(\mathrm{p}<0.05)$ as the time these dispersion units were exposed to $40^{\circ} \mathrm{C}$ increased and relative humidity of $100 \%$. However, the final germination percentage was not influenced by the AA time. Diaspores not submitted to AA presented $44 \%$ germination, whil etho seexposedto $40{ }^{\circ} \mathrm{C}$ for 72 hours presented $39 \%$.

Tabela 3. Valores de condutividade elétrica $\left(\mu \mathrm{Sm}^{-1} \mathrm{~g}^{-1}\right)(\mathrm{C} . \mathrm{E})$, porcentagem de germinação (\%) (PG), tempo médio de germinação (TMG), índice de velocidade de germinação (IVG), e sincronização (U) de diásporos de C. myrianthum após envelhecimento acelerado em diferentes períodos (horas).

Table 3. Electric conductivity values $\left(\mu \mathrm{S} \mathrm{cm}^{-1} \mathrm{~g}^{-1}\right)(\mathrm{EC})$, germination percentage (\%) (GP), mean germination time (MGT), germination speed index (GSI), and synchronization (U) of C. myrianthum diaspores after accelerated aging in different periods (hours).

\begin{tabular}{cccccc}
\hline AA hours & $\begin{array}{c}\text { EC } \\
\left(\mu \mathrm{S} \mathrm{cm}^{-1} \mathrm{~g}^{-1}\right)\end{array}$ & $\begin{array}{c}\text { GP } \\
(\%)\end{array}$ & $\begin{array}{c}\text { MGT } \\
(\text { days })\end{array}$ & GSI & U \\
\hline 0 & $68.61 \mathrm{a}$ & $44 \mathrm{a}$ & $13.29 \mathrm{c}$ & $27.58 \mathrm{a}$ & $2.54 \mathrm{a}$ \\
24 & $38.91 \mathrm{c}$ & $37 \mathrm{a}$ & $15.41 \mathrm{ab}$ & $11.61 \mathrm{~b}$ & $2.71 \mathrm{a}$ \\
48 & $55.02 \mathrm{~b}$ & $35 \mathrm{a}$ & $16.37 \mathrm{a}$ & $15.80 \mathrm{~b}$ & $2.90 \mathrm{a}$ \\
72 & $56.43 \mathrm{~b}$ & $39 \mathrm{a}$ & $13.76 \mathrm{c}$ & $14.96 \mathrm{~b}$ & $2.77 \mathrm{a}$ \\
\hline C.V $(\%)$ & 12.49 & $17.85 \%$ & $9.40 \%$ & $28.82 \%$ & $12.17 \%$ \\
\hline
\end{tabular}

Means followed by the same letter do not differ from each other by the Tukey test at $5 \%$ probability.

Despite the reduction in EC values, it is noteworthy that the variables MGT (days) and GSI were sensitive to AA, the longer the diaspores underwent aging conditions, the higher the MGT after 24 and 48 hours of exposure to AA, and the lower the GSI for all aging exposure periods when compared to the control (0 hours) (Table 3 ).

The germination frequency results of $C$. myrianthum diaspores obtained after different AA periods are shown in Figure 2. It is observed that the species has a high frequency and high synchronization index of the germination process for both the control and the different AA periods, meaning that the species presented spaced out germination over time. However, germination begins on the third day after 24 and 48 hours of AA, and peaking on the $7^{\text {th }}$ day. In contrast, germination in the treatment after 72 hours of AA begins on the second day, with a peak on the $6^{\text {th }}$ and $7^{\text {th }}$ days. 

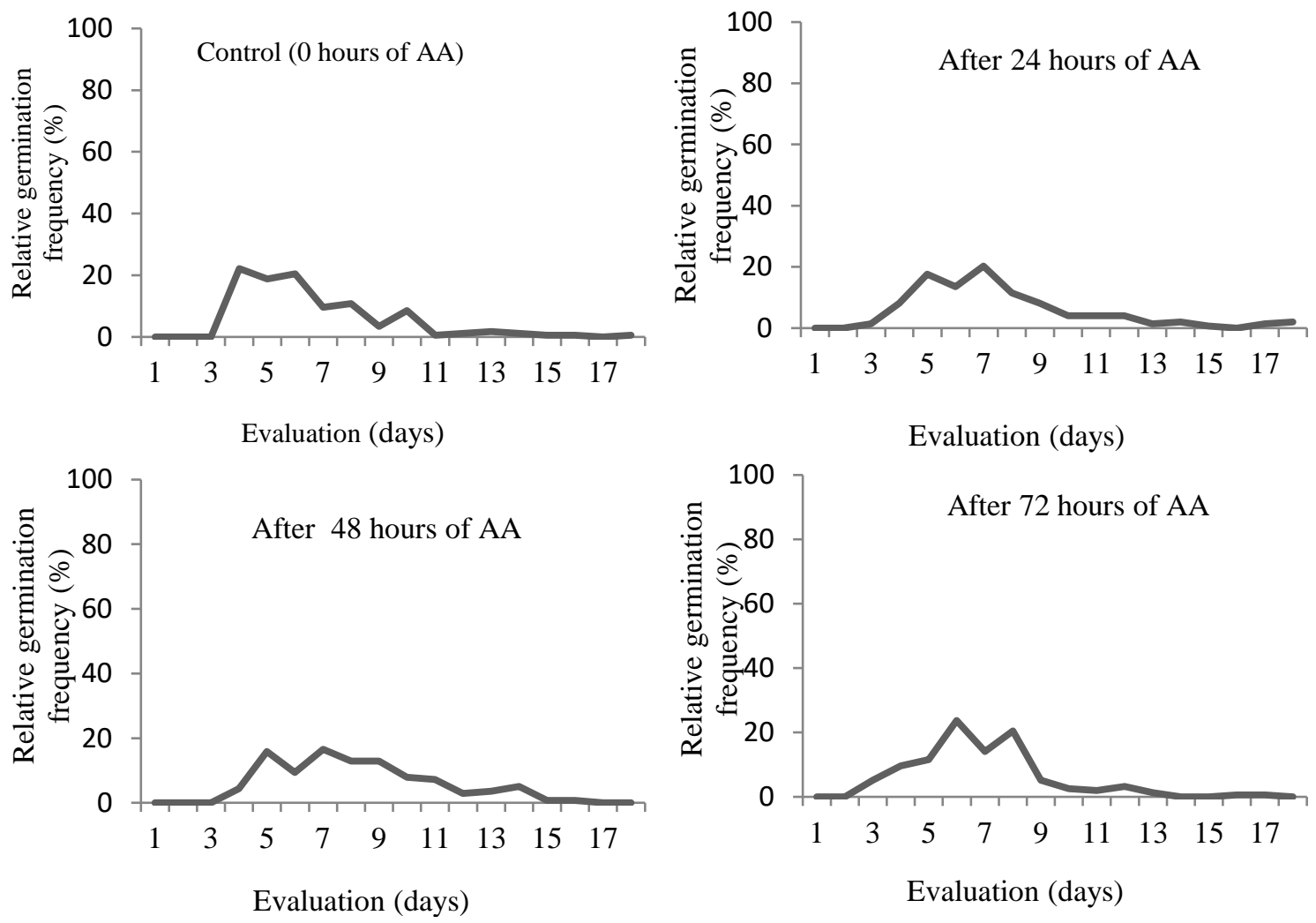

Figura 2. Frequência relativa da germinação (\%)de diásporos de C. myrianthum após diferentes períodos de envelhecimento acelerado (E.A)(0, 24, 48 e 72 horas).

Figure 2. Relative germination frequency of $C$. myrianthum diasporas after different accelerated aging periods (AA) ( 0 , 24, 48 and 72 hours).

\section{DISCUSSION}

This work observed a water content of $8.8 \%$ and a mass of one thousand seeds of $66.6 \mathrm{~g}$. The water content and mass values of 1000 seeds were lower when compared to those found in Zanon et al. (1997), where the authors obtained a water content of $13.0 \%$ and a mass of 1000 seeds of $59.1 \mathrm{~g}$ in their study with C. myrianthum; and Amaral et al. (2013) whoobtained a water content of $14.7 \%$ in diasporas that were in anointer mediate/mature stage of development. These authors describe intermediate/mature diaspores as those which present characteristics of dry matter weight of the pyrenes corresponding to $37 \%$ of the dry weight of the fruit; reddish yellow coloration; and higher germination percentage (GP) when compared to green fruits, namely $46 \%$ in intermediate/ripe fruits and $30 \%$ in green fruits.

Knowing the water content of diaspores when dispersed is important, as it is known that a hot and humid environment is favorable for seed deterioration during storage, so seeds that have their full stage of development have higher quality because fruits tend to gain water, and diaspores lose it during ripening. In seed formation, moisture decreases as dry matter increases to the point where the water content of the seed fluctuates with the humidity of the environment (AMARAL et al., 2013).

The GP value observed in this study for $C$. myrianthum diaspores was $44 \%$, being close to the value observed in the study by Amaral et al. (2013) and Zanonet et al. (1997), who obtained 46\% and 40.2\% GP, respectively. In addition to a low GP, it is observed that this species presents unevenness in the germination process (Figures 1 and 2 ).

The germination characteristic spread over time may be a property of forest species, classified as pioneer to early secondary, which contributes to forming a seed bank (AMARAL et al., 2013). The author also states that the formation of a seed bank can play an important role in maintaining the genetic base of $C$. myrianthum populations in situations where previously existing trees have been eliminated, or even helps to mitigate the effects caused by periods of lower fruit production. The fact that they remain viable for a long period in the soil and because of their light weight and high buoyancy justify that this species may suffer secondary dispersion by water, increasing the likelihood of colonization of new areas. It can also be mentioned that the germination unevenness may be an occupation strategy of the species, enabling their emergence from time to time, reducing the competition between the newly formed seedlings (AMARAL et al., 2013; MORAES et al., 2016).

In comparing the results obtained in this work with those obtained for the Bauhinia forficata Link species, it is observed that this species, also considered a pioneer in ecological succession, has low GP ranging from $8 \%$ to $49 \%$, which is attributed to the dormancy of its seeds (GUARESCHI et al., 2015). The Tabernaemontana fuchsiaefolia A. DC 
species alsopresents spread out germination over timeand with several peaks which contributes to forming the seed bank, and is similar behavior to C. myrianthum (MORAES et al., 2016).

Regarding the results obtained in this study, it is noteworthy that the use of $100 \mathrm{~mL}$ of water reduced the EC values by almost half $\left(18.13 \mu \mathrm{S} \mathrm{cm}^{-1} \mathrm{~g}^{-1}\right)$ for the adequacy of the EC test, as observed in Table 1 when analyzing the unfolding of the factor number of diaspores in relation to the water volume. Delazeriet et al. (2016) reportsthatincrea sing the volume of deionized water used in the test solubilizes the exudates releasedduringthesoaking process, thusreducingtheobtained EC values. In a work with Bowdichia virgilioides Kunth. seeds, a pioneer species indicated for recovering degraded areas, Dalanhol et al., (2014) demonstrated a reduction in EC values with the use of $100 \mathrm{~mL}$ of deionized water, indicating that the use of a smaller deionized water amount of 75 or even $50 \mathrm{~mL}$ for the EC test would be more efficient in characterizing the vigor of the seedlots of the species under study.

Regarding the water volume and immersion period of $C$. myrianthum diaspores (Table 2), there is an increase in the release of electrolytes by diaspores over immersion time in deionized water. Similar results were obtained by Flávio and Paula (2010) in working with Dictyoloma vandellianum A. Juss. seeds, where the EC values increased over soaking time in smaller volumes of water and with a smaller number of seeds. Medeiros et al. (2017) also observed an increase in EC values over time for Moringa oleifera Lam. seeds belonging to the Apocynaceae family.

It is noteworthy that there is the adherent fruit pericarp associated with the $C$. myrianthum seeds, a factor which can make the seed extraction difficult in native forest species, since the morphological and structural structures of the fruit prevent or hinder the soaking process by being present, or even change the amount of leached solutes in the electrical conductivity test. In addition, vigor tests are formulated from highly domesticated and genetically improved agricultural species, and considering the large variability among seeds of native species in the wild, it is common to observe large variation in results, thus requiring adaptation of methodologies and caution in interpreting the information (SABONAROet al., 2017).

Regarding accelerated aging, it is known that this technique generates a series of oxidative reactions leading to lipid peroxidation, damaging membranes, causing loss of reserves and degradation of metabolites essential for germination, promoting loss of viability and deterioration of the seeds, thus evidencing the vigor of the seeds since vigorous seeds have mechanisms that prevent this deterioration (MORAES et al., 2016). However, when analyzing the germination of $C$. myrianthum diaspores after different AA periods (Table 3), it was found that there was no significant difference between treatments for the GP variable, so this parameter would not be indicated for seed lot distinction regarding the vigor for the $C$. myrianthum seeds.

Regarding the analysis the EC variable, it was observed that there was a decrease in values as the exposure time to AA increases. Flávio and Paula (2010) describe that there is no defined leaching pattern by native seeds of different species. It can be emphasized that this reduction in EC values and the non-significant difference in GP values from the control ( 0 hours) shows that $C$. myrianthum diaspores are tolerant to stress generated during the AA test, suggesting that perhaps using higher temperatures, longer test periods, or saline treatment may promote more discrepant data so that different lots can be distinguished.

Although Amaral et al. (2013) did not report any type of dormancy in C. myrianthum diaspores in their study, it is noteworthy that the low GP coupled with the drop in conductivity value during the accelerated aging test may be related to an integumentary dormancy present in the species, and that the high temperature and humidity of the air present in the AA test may help to overcome dormancy. Dormancy is an acceptable hypothesis in this study because the chemical analysis performed by Amaral et al. (2013) revealed that $C$. myrianthum is a starchy fruit (50\% of the sample is starch) and have a high fiber rate (30 to $35 \%$ of the sample), which is accumulated in the outer layer of the pyrene.

Araujo et al. (2017) in working with Leucaena leucocephala (LAM.) de Wit.,Guareschi et al. (2015) withB. forficata, and Moraes et al. (2016) withT. fuchsiaefolia, also failed to obtain significant difference in GP when the AA test was conducted at $41^{\circ} \mathrm{C}$, as observed in this study with $C$. myrianthum diaspores. In this case, the variables that stood out in relation to the others to identify the most vigorous lots were GST, first germination count and the MGT, as these are more sensitive factors to the conditions under which the test is performed.

These changes in the MGT and GSI indicate that the germination process is affected by the AA test, because the temperature changes the activity of enzymes responsible for mobilizing energy reserves, thus expressing that the changes related to vigor reach biochemical levels and not just disorganization in the plasma membrane (MARCOS FILHO, 2015). Another noteworthy fact is that most forest seeds have dormancy, which makes it difficult to discriminate the vigor of the seed lots by techniques used for commercial species, and therefore the use of more sensitive variables such as GSI and MGT may be an alternative in analyzing the vigor of these species.

\section{CONCLUSIONS}

The analyzes carried out concluded that:

- $\quad$ The electrical conductivity test for $C$. myrianthum diaspores can be conducted with 25 diaspores soaked in $50 \mathrm{~mL}$ of deionized water for 96 hours.

- $\quad$ The 24 and 48-hour period is best suited to conduct the accelerated aging test.

\section{ACKNOWLEDGEMENTS}

The authors thank the Forest Nursery of the Bela Vista Biological Refuge of ITAIPU Binacional for making the Citharexylum myrianthum diaspores available.

FLORESTA, Curitiba, PR, v. 49, n. 4, p. 701 - 708, out/dez 2019. 


\section{REFERENCES}

ALMEIDA, D. S. DE. Recuperação ambiental Mata Atlântica. Ilhéus: Editus, $3^{\circ}$ ed. 2016, 200 p.

AMARAL, W. A. N. do.; ANTIQUEIRA, L. M. O. R.; HORBACH, M. A. Frutification and germination ecology of Citharexylum myrianthum Cham (Verbenaceae). Journal of biotechnology and biodiversity, v. 4, n. 3, p. 207-215, 2013.

ARAÚJO, F. S.; FÉLIX, F. C.; FERRARI, C. dos. S.; BRUNO, R. de. L. A.; PACHECO, M. V. Adequação do teste de envelhecimento acelerado para avaliação do vigor de sementes de leucena.Revista Brasileira de Ciências Agrárias Brazilian Journal of Agricultural Sciences, Pernambuco, v. 12, n. 1, p. 92-97, 2017.

AOSA - ASSOCIATION OF OFFICIAL SEED ANALYSTS.Seed vigor testing handbook. East Lasing: AOSA, 1983, 93 p.

BRASIL, Ministério da Agricultura Pecuária e Abastecimento. Regras para Analise de Sementes. Brasília: MAPA/ACS, 1 ed. 2009, 399p.

BRASIL, Ministério da agricultura, Pecuária e Abastecimento. Instruções para Análise de Sementes de Espécies Florestais. Brasília: MAPA/SDA, 1 ed. 2013, 97p.

DALANHOL, S. J.; REZENDE, E. H.; ABREU, D. C. A. de.; NOGUEIRA, A. C. Teste de condutividade elétrica em sementes de Bowdichia virgilioides Kunth. Floresta e Ambiente, Rio de Janeiro, v. 21, n. 1, p. 69-77, 2014.

DAVIDE, A. C.; CARVALHO, L. R. de.; CARVALHO, M. L. M. de.; GUIMARÃES, R. M. Classificação fisiológica de sementes de espécies florestais pertencentes à família lauraceae quanto a capacidade de armazenamento. CERNE, Lavras, vol. 9, n. 1, p. 29-35, 2003.

DELAZERI, P.; GARLET, J.; SOUZA, G. F. Teste de condutividade elétrica em lotes de sementes de Schinusmolle L. Floresta e Ambiente, Rio de Janeiro, v. 23, n. 3, p. 413-417, 2016.

FLÁVIO, J. J. P.; PAULA, R. C. Testes de envelhecimento acelerado e de condutividade elétrica em sementes de Dictyoloma vandellianum A. Juss. seeds. Scientia Forestalis, Piracicaba, v. 38, n. 87, p. 391-399, 2010.

FUNDAÇÃO SOS MATA ATLÂNTICA; INPE. Atlas dos remanescentes florestais da Mata Atlântica período 2016-2017; relatório técnico. São Paulo: Fundação SOS. 2018. 63 p.

GUARESCHI, D. G.; LANZARINI. A. C.; LAZAROTTO, M.; MACIEL, C. G.; BARBIERI, G. Envelhecimento acelerado de sementes e qualidade de plântulas de Bauhinia forficata Link em diferentes substratos e tamanhos de tubetes. Revista Agro@mbiente On-line, Boa Vista, v. 9, n. 1, p. 67-71, 2015.

LABOURIAU, L. G. A germinação de sementes. Washington: Organização dos Estados Americanos, 1983,174 p.

LORENZI, H. Árvores Brasileiras - Manual de Identificação e Cultivo de Plantas Arbóreas Nativas do Brasil. Nova Odessa: Instituto Plantarum, $6^{\circ}$ ed. 2014, 384 p.

MACHADO, D. F. M.; BORTOLIN, G. S.; PARANHOS, J. T.; SILVA, A. C. F. da. Temperatura, luz e desinfecção na germinação das sementes de Gochnatia polymorpha (Less.) Cabrera. Revista de Ciências Agrárias, v. 1, n. 39, p. 144$152,2016$.

MARCOS FILHO, J. Fisiologia de sementes de plantas cultivadas. Londrina: Associação Brasileira de Tecnologia de Sementes - ABRATES, $2^{\circ}$ ed. 2015, 615-648 p.

MEDEIROS, M. L. de. S.; PÁDUA, G. V. G. de.; PEREIRA, M. D. Adaptação do teste de condutividade elétrica para sementes de Moringa oleifera. Pesquisa Florestal Brasileira, Colombo, v. 37, n. 91, p. 269-275, 2017.

MMA - Ministério do Meio Ambiente. Biomas -Mata Atlântica. Disponível em: <http://www.mma.gov.br/biomas/mata-atlantica>. Acesso em: 06set. 2018.

MORAES, C. E.; LOPES, J. C., FARIAS, C. C. M.; MACIEL, K. S. Qualidade fisiológica de sementes de Tabernaemontana fuchsiaefolia A. DC em função do teste de envelhecimento acelerado. Ciencia Florestal, Santa Maria, v. 26, n. 1, p. 213-223, 2016.

NAKAGAWA, J. Testes de vigor baseados na avaliação das plântulas. In: VIEIRA, R. D.; CARVALHO, N. M. Testes de vigor em sementes. Jaboticabal: FUNEP, 1994. 49-85 p.

RANAL, M. A.; SANTANA, D. G. How and why to measure the germination process? Revista Brasileira de Botânica, São Paulo, v.29, p.1-11, 2006.

SABONARO, D. Z.; PRUDENTE, C.; BARBEDO, C. J. Estruturas do fruto de aroiro na qualidade de sementes através do teste de condutividade elétrica. Revista trópica: Ciências agrárias e biológicas, v. 09, n. 01, p. 86-97, 2017.

SOS Mata Atlântica - Projetos -Atlas da Mata Atlântica - Dados Mais Recentes. Disponível em: <https://www.sosma.org.br/projeto/atlas-da-mata-atlantica/dados-mais-recentes>. Acesso em: 06 set. 2018.

ZANON, A.; CARPANEZZI, A. A.; FOWLER, J. A. P. Germinação em laboratório e armazenamento de sementes de Tarumã-Branco (Citharexylum myrianthum CHAM.). Boletim de pesquisa florestal, Colombo, n. 35, p. 75-82, 1997. 